\section{The impact of Development Perspective of HRM and Lesson Learned System of Knowledge Management on Project Success}

\author{
Sumera Asgher butt ${ }^{1}$ Bilal Ghaffar ${ }^{2}$ Kamran $\mathrm{Ali}^{3}$
}

The Journal of Educational Paradigms 2019, Vol. 01(01) 1-12

(C) Authors

ISSN (Print): 2709-202X

ISSN (Online): 2709-2038

DOI: $10.47609 / 0101012019$

\begin{abstract}
The impact of the development perspective of human resource management and lesson learned system of knowledge management on project success. The mediating role competency retention is examined by collecting the data from the regular employees of the telecommunication sector. A total of 380 questionnaires distributed, out of which 321 questionnaires were returned, and the study gained an actual response rate of $84.4 \%$. Some surveys were excluded because of missing values using the list-wise deletion method, which includes a statistical analysis, and after that, 310 complete questionnaires were selected for further proceedings. The results confirmed that the development perspective of human resource management and lesson learned system of knowledge management has an insignificant positive relationship with project management competency retention and project success. There is no mediation of project management competency retention that has been proved between the development perspective of human resource management, and lesson learned system of knowledge management, and project success. A significant positive relationship has been shown between project management competency retention and project success. Finally, the results suggested that the organizations must retain competency to achieve project success.
\end{abstract}

Keywords: development perspective, Human resource management, knowledge management, project management competency retention, project success.

The success of any organization can be measure from the success of their projects. Numerous project management scholars have described project success and the aspect that has an impact on the success of the Project. Project management scholars are still working to identify the managerial factors that impact project success (Shenhar, Levy, O, \& Davir, 1997). Many scholars study the same thing mentioned by Liu and Walker on project success, but it remains the least agree upon (Liu \& A, 1998). However, the topic of project success is considered most frequently studied, but only a few researchers have seriously worked on it (Wateridge, 1998). The theme of project success found very interesting to different people due to different ideas, which result in the disagreement about whether the Project is successful or not (Liu A., 2005).

Projects play an important role in implementing strategies in the organizations so we can say that the success in projects represents the success of the business and creates a long-term positive image of the organization (Meshkendahl, 2010). In the beginning, Project was considered successful if it was completed within due time, a term mentioned, the budget allocated, and expected quality is achieved.

The concept of knowledge in project management has shown that the project success does not only depend on these factors, but it's also a complicated and multidimensional approach that consists of many attributes (Mir, F.A, \& Pinnington, 2014). Project success is defined as the degree to which project goals and expectations are met. It should be viewed from different perspectives of individuals and the purposes related to a variety of elements, including technical, financial, education, social, and professional issues. Project success is the goal, and the objectives of budget, schedule, and quality are the three normally accepted criteria to achieve the goal (Elattar, 2009).

For the success of a project, the organization needs to retain its competent employees. Today winning and growing organizations are those who have a high level of competencies. According to Burnett and Dutch skills play an important role in the survival of the organization. Knowledge, experience, and interest in work enable the managers to be successful in his/her job (Burnt \& Dutsch, 2013). Bernard and Appolonius stated that the organization retains competency when it provides monetary benefits, security, career, and a better environment to its employees (Bernard, Oyagi, Appolonius, \& Kembu, 2014). A study conducted in Ghana Vodafone company and was founded that competency can be retained by an organization when it satisfied their employees' needs, provide a career path, and better working environment to its employees (Kwenin, Muathe, \& Nzulwa, 2013). Retaining competent employees is very beneficial for the organization. When retaining their skilled employees, organizations enable it to fulfill its goals and objectives, and employers should have the ability to hire competent employees at least longer than its competitor. An organization should learn to retain its competent employees at different levels, and it starts at a time when employees are hired (Madiha et al., 2009).

Knowledge management is considered one of the most important factors for the success of a project and performance of an organization (Alavi \& Leidner, 1999), (Kotnour T., 2000),

${ }^{123}$ Lecturer, Department of Commerce, University of the Punjab, Gujranwala Campus. Corresponding author: bilal.ghaffar@pugc.edu.pk 
(Nonaka \& Takeuchi, 1995). Knowledge is a valuable source that is transferred to an organization from its employees' ability, and it is an essential source of getting a competitive advantage (Drucker, 1993). (Hoegl \& Schulze, 2005) it evolves from the individual mind, and it differs from individual to different and cannot be easily shared (Nonaka I., 1994). Lesson learned systems are useful in the project-based organization, and by adopting a lesson learned order, the performance will not be affected even when employee leave/ the organization (Caldas \& Gibson, 2009). There are a few reasons that force a project-based organization to adopt a lesson learned system most important is that it enables organizations not to repeat the mistake that took place in the past projects. To make sure the thing that allows recent project success has been adopted or not in the present project, to get a competitive advantage and to ensure innovation in the current project compared to the previous one (Paranagamage \& Carrillo, 2012).

Project managers record their output and efforts during the projects to be used in the future when required. The project-based organization has taken a wise step by adopting a learned lesson system, but the advantage of learning has not yet made in proper manners (Paranagamage \& Carrillo, 2012). Lesson learned has enabled us to use it at the time of need, but it is also necessary to check the reliability with time. The project-based organization needs to have a system which conveys the lesson learned to the employees at the time when they are working on the project. Even it is crucial for every project-based organization to have a proper lesson leaned system and lesson capturing system. Because it would not be a problem for them when employees leave the organization as the organization is not entirely dependent on individual employees (Senaratne \& Malewana, 2011). Many organizations in the field of construction learned that the learned lesson system is beneficial for the management of knowledge (Caldas \& Gibson, 2009). An organization that has better management of knowledge can perform better and gain strength in competitive advantage (Riege, 2007). Successful organizations know the importance of knowledge management and see the gravity of the importance of knowledge management to enhance the organization (Teece \& Pisano, 1997). One of the important sources for the survival of an organization is that the organization must take full benefit of knowledge (Dul, Canan, \& Ceylan, 2011). HRD is a function that not only deals with the improvement of organizations but also the growth of the individuals (Fenwick \& Bierema, 2008). Individual development should be considered an important part of the HRD, and special attention should be given to improve individuals' performance (Kuchinke, 2010). HRD/HRM can provide an environment for cooperation among the employees and build trust and common culture in the organization (Collins \& Smith, 2006). HRD practitioners should be supportive and open to talking to employees and coaching to increase knowledge productivity and social interaction between the employees within the organization to enhance their innovative behavior (Swart, 2012). Organizations use human resource techniques to build a suitable attitude in the organization a proper employees' knowledge and capabilities to increase productivity and performance (Bates \& Chen, 2004). It is a necessary human resource management process to enable learning in the organization for the employees for the organization's better productivity (Gubbins \& Garavan, 2006).

\section{Development of Hypotheses}

The section below is consisting of hypotheses formulation that supported literature, as discussed above. This form provides an analogy between practical and theoretical reasoning.

\section{perspectives of HRM and PMCR}

In most of the organization, projects are short-term process, so projects managers do not get a proper career path in this line as once the project completes, projects managers will no longer remain with that organization. So, project managers stay at a position for a short period as compared to the line manager. It is crucial to provide a career path to the project manager, which should be according to their qualification and experience and comparable with the line organizations. Most of the well-reputed organizations have not adopted this structure. Whereas, most of the studies have mentioned that providing career opportunity helps the organization retain its employees and has a significant positive impact on the retention of the employees (El-Sabaa, 2001). When an organization promotes its internal employees based on their performance, this thing enhances the performance of the employees, and employees remain with the organization. Numerous studies have supported that promoting employees based on performance has a negative relation with turnover (Guthrie, 2001). When an organization provides career opportunities to its employees, then it would indirectly have a negative impact on their intention to leave the organization (Allen \& Shore, 2003). According to Laser, providing proper training to employees is also a vital tool to eliminate the issue of turnover. Formal training to employees has a positive impact on employee retention, and it also enhances the employees (Laser, 1980). Providing job-related training to employees has a positive effect on the retention of the employees. Development perspective and training opportunities to employees have a negative impact on turnover intention of the projects managers and when they remain with the organization and deals with different projects and learn from their experience ultimately their competencies enhance which results in high performance and when these managers with such competencies promoted to top managements then goals of the organization will be achieved easily (Zollo \& Winter, 2002). HRD has a significant impact on employee performance and increases their level of commitment and knowledge (Indradevi, 2010).

The purpose of the creation and enforcement of the HRD program is to enhance employees' ability to get desired outcomes (Indradevi, 2010). According to Bell and Kozlowski, the competency of the employees increases when they consider HRD beneficial and organization encourage them to participate in the learning process (Bell \& Kozlowski, 2008). All branches of HRD help organizations increase the employees' competency and enable them to learn new knowledge and skills that ultimately increase the organization (Noe, Tews, \& Dachner, 2010).

Hypothesis 1: There is a significant Positive relationship between Development Perspective of Human Resource Management and Project Management Competency Retention.

\section{Development Perspective of HRM and Project Success}


Human resource plays a vital role in the success of an organization. An environment should be created where the elements of a project are managed with perfection to achieve project success (Kerzner, 1987). Many organizations have moved from conventional to project management, but human resources play an important role in the success of both traditional and project-based organizations. Mostly the human resource management processes are for the permanent organization where employees have fixed positions and not for the project-based organization where project managers have no specific position (Packendorff, 2002). In stable organizations, employee training is arranged formally. Whereas, in the project-based organization, the project manager takes more responsibility and less time to complete the project, so they work more to complete the project in time. These circumstances have forced to create a new strategy of human resource development for the project-based organizations. It has created a new way of recruiting employees for a short-term basis for the specific project and career development. HRD has a significant impact on the performance of the employee sand increases their level of commitment and knowledge (Hutchings, Zhu, \& Cooper, 2009). The performance of the employees' increases, and they work more dedicated to achieving the organization's objectives. The organization's support and incentive are equal to or greater than the output of the employee (Masterson \& Stamper, 2003). This support and incentives increase the level of commitment of the employees, and employees contribute more to the organization. Adequate human resource management allows employees to participate and perform the organization's operations effectively and efficiently to achieve the organization's goals and objectives (Susan, 2012). Human resource management consists of guidelines, training, and processes that impact the attitude, behavior, and outcome of the employees. Human resource management is considered as the most important and beneficial asset of the organization.

Hypothesis 2: There is a significant Positive relationship between Development Perspective of Human Resource Management and Project Success.

\section{Lessons learned systems of KM and PMCR}

Providing learning and knowledge sharing opportunities helps retain competency in the organization for an extended period. Developing a culture of knowledge sharing in the organizations is an important factor in retaining skills and reducing turnover. Those organizations that enhance knowledge sharing culture can maintain their employees (Smith \& Oczkowski, 2011). According to Grant, those organizations that foster learning and knowledge sharing are more able to retain competency and get a competitive advantage (Grant, 1996). When the projects complete, project managers transfer to different departments without keeping the lesson learned by them. Undoubtedly, the lesson learned by them during the project enhances their competency, which remains with the organization for the successful completion of the future projects (Disterer, 2002). When managers share a lesson learned by them during the execution of the projects with each other, their ability to deal with projects enhances, and by this, they would be able to deal with the future project more effectively and efficiently (Newell \& Edelman, 2008).
Lesson learned is the process of knowledge creation based on the information collected from the previous project and stored, which is then used at the start of the new project in a new way. It is a process of converting the individual knowledge into the organizational knowledge (Nonaka, 1994). Lesson learned is used to enhance the competency by sharing project managers' experience, which is then used for the execution of new projects to get the desired outcome (Zollo \& Winter, 2002). The creation of proper storage of lesson learned system used to retain the competency of the project managers. Lesson learned is considered as a critical factor for retaining project management competency. The adoption of knowledge management strategies adds value to the organization outputs. Any organization has extensively adopted this strategy. It has enhanced the performance of adopted organizations reported by numerous scholars (Gholami \& Asli, 2013). However, (Tseng, 2014) lesson learned system is seen very useful in the project-based organization, and by adopting a lesson learned the system, the performance will not be affected even when employee leave/ the organization. According to (Paranagamage \& Carrillo, 2012), a few reasons force projectbased organizations to adopt the lesson learned the system. It is essential because it enables the organization not to repeat the mistake that took place in past projects to ensure the thing that allows past project successful has adopted or not in the existing project, to get a competitive advantage and to ensure innovation in the present project as the compared previous one.

Hypothesis 3: There is a significant Positive relationship between Lesson Learned System of Knowledge Management and Project Management Competency Retention.

\section{Lesson learned System of KM and Project Success}

Knowledge plays an important role in getting a competitive advantage, adopting innovation, and success of projects. Some argue that the innovations in an organization mainly depend on the knowledge and competency of its employees. It is important to have effective management for storage, utilization, and sharing of knowledge (Egbu, 2000). Knowledge transfer has seen very fruitful for those organization which is connected (Darr \& Argote, 1995) like groups (Baum \& Ingram, 1998) and franchise (Powell $\&$ Koput, 1996) and these organization share knowledge more effectively as compared to the independent organizations. Knowledge sharing is one factor that helps the organization gain a competitive advantage (Argote \& Beckman, 1990). The goals and objectives of the organization can be achieved in a perfect way when the learning in the organization is regularly (Cyert \& March, 1963). Knowledge management is considered one of the most important factors for the success of a project and the performance of an organization. Knowledge is an important source that is transferred to an organization from the ability of its employees, and it is an important source of getting a competitive advantage (Drucker, 1993). Methods of knowledge management should be followed at the start of the project, and at the end of the project, all the lessons learned from that project should be collected (Owen \& Burstein, 2005).The organization's value increases when knowledge is shared and distributed among the employees (Choi, Kim, \& C.M, 2006). Knowledge will be useless when it is not utilized effectively and efficiently (Yusof \& Bakar, 2012). 
Knowledge management is an important issue for getting a competitive advantage for the long-term (Alavi \& Leidner, 1999). Implementing a knowledge management strategy in the organization enables organizations with value and quality of performance (Spender \& Grant, 1996). Numerous researches have been done to discover the impact of knowledge management on the success of a project (Suraj \& Ajiferuke, 2013) and (Tseng, 2014) knowledge management is an important process in enhancing the performance of the organization. Knowledge gain in terms of response from the customers helps the organization increase the performance of the project and helps create a good relationship with the customer, ultimately enhancing the performance of the customer's projects and satisfaction (Abdullateef \& Mokhtar, 2010). From the past decade, knowledge formation in the organization has become an important element of empirical and theoretical studies (Becerra-Fernandez, 2001). Knowledge formation is the method to evaluate the lesson delivered by the employees and to link and save it with the organizational knowledge system (Nonaka \& Toyama, 2000). Recently, several organizations have been adopting knowledge for the successful outcome of their projects, and in the recent years (Metaxiotis \& Ergazakis, 2005) number of studies have been conducted on the importance of knowledge management. (Goh, 2002) support knowledge management as an important branch and suggested implementing knowledge management in the public organization for the improvement of operations in the public sector. It is possible when officials want it to be implemented as in the process of knowledge management. knowledge is shared among different organizations, which would be proved beneficial for the involved organizations, and it is possible only when the authorities show their consent in this matter. Learning is crucial for getting a competitive edge. Today in this competitive environment, every organization wants success in its projects and wants to achieve tremendous progress, which is possible only with an effective knowledge management system (Grant, 1996). Learning has an impact on the performance of the organization, especially in adopting new technology and in the progress of the new product. It is adopted to combine employees and make them smart, innovators, a better decision-maker (Patton, 2001). Learning is crucial and beneficial for the newness of the project in the project-based organization as learning improve the skill of the employees and enable the organization to present their project in a better form (Sammarra \& Biggiero, 2008). Their performance enhances and learning to enable them to move with the market. According to (Paranagamage \& Carrillo, 2012) few reasons force project-based organizations to adopt the lesson learned system most important is that it enables organizations not to repeat the mistake that took place in the past projects. to make sure the thing that enables past project success has adopted or not in the present project, to get a competitive advantage and to ensure innovation in the present project as compared to the previous one. When there is no proper system for managing knowledge and the learned lesson system, it will result in improper delivery of the project, leading to customer dissatisfaction. It is very harmful to the organization's image in a competitive environment (Desouza \& Paquette, 2011). Moreover, (Devenport \& Prusak, 1998), knowledge management has gained a lot of attention from the management scholar. It was considered the most important factor for the success of the projectbased organization and gained the strength in competitive advantage.

Hypothesis 4: "There is a significant Positive relationship between Lesson Learned System of Knowledge Management and Project Success".

Project Management Competence Retention and project success

Retaining competent employees is very beneficial for the organization and organization when retaining its skilled employees; it enables it to fulfill its goals and objectives. Organizations should have the ability to retain their competent employees at least longer than its competitor. Organizations required competency for competitive advantage, and employees need career and competency and skill development opportunities (Prince \& Van Eijs, 2005). Providing competency development chances to an employee is beneficial for both organization and employees, and doing so, the organization gains a competitive advantage. In contrast, employees gain an opportunity to enhance their competencies. The organization fails to retain skills when an organization does not provide career opportunities to its employees, and organizations face negative output from their employees (Taylor \& Audia, 1996). The organization fails to retain competency as the project managers face time pressure, stress, and conflict. Such an environment results in a loss of skill (Turner \& Keegan, 2008). Many organizations fail to retain their project managers (Holzle, 2010). Project managers face stress and time and work burden, which positively linked with quitting the job (Aitken \& Crawford, 2007) and that the time when they seek the support of the organization (Cao \& Hirschi, 2014). The competency of a project manager plays a vital role in delivering the project successfully. A mixture of knowledge and ability of the manager (Crawford, 2007) competency needed by project managers varies and depends on the nature of the project (Muller \& Turner, 2007). Therefore, it is an important work for the project manager to tackle the different situations effectively and efficiently. The main task of project managers is to use their competency to collaborate with members and perform functions according to the project management schedule and within a specific time. To complete the task, a project manager should have a competency to efficiently and effectively fulfill the work (Crawford, 2000). Project managers are required to combine their entire competence to collaborate and communicate with team members to perform the given task and to get desire results. Organizations deals with project and number of projects are being failed. Therefore (Bredillet \& Tywoniak, 2015), organizations need competency for quick results, which increases the demand of project managers (Crawford, 2005).

Fast-growing organizations demand competent project managers for sensitive issues that not only deal with projects but also collaborate and communicate to resolve unethical matters. Hence, researchers have presented a series of competencies that project managers (El-Sabaa, 2001) and (Crawford, 2005). The project manager should possess a high-level competency to achieve success and avoid failure (Napier \& Keil, 2009). Project 
management competency is to figure out business operations and know-how of skills and understanding of business surroundings (Suikki \& Tromstedt, 2006). For better performance, it is crucial to determine the competency of every member and tie them to a single aim to achieve high performance (Maznevski, 1994). Research reveals that it is fruitful for the organization to attain collective competency (Ruuska \& Teigland, 2009). Skill plays a vital role in the success of a project (Jha \& Iyer, 2007).

Hypothesis 5: There is a significant Positive relationship between Project Management Competency Retention and Project Success. Development Perspective of HRM and Project Success with mediation of PMCR

Most of the studies have mentioned that providing career opportunity help the organization to retain its employees, and it has a significant positive impact on the retention of the employees. When organization promotes their internal employees based on their performance, then this thing enhances the performance of the employees and employees remain with the organization and numerous studies have supported that promoting employees based on performance has a negative relation with turnover (Guthrie, 2001). When an organization provides career opportunities to its employees, then it would indirectly have a negative impact on their intention to leave the organization (Allen \& Bryant, 2010). In the same way, when organizations provide promotion opportunities to their employees, it also negatively impacts their intention to leave the organization (Phillips, 1998). Providing a proper career path to project managers helps the management to retain project managers in the organization (Bredin \& Soderlund, 2013). Providing adequate training to employees is also significant for tools to eliminate the issue of turnover. Formal training to employees has a positive impact on the retention of the employees, and it also enhances the competency of the employees (Laser, 1980). (Huselid, 1995) also supported that providing job-related training to employees have a positive impact on the retention of the employees. When an organization offers learning chances to enhance employee competency, it also has a negative effect on their intention of turnover ( $\mathrm{Ng} \&$ Butts, 2009). Development perspective and training opportunities to employees have a negative impact on turnover intention of the projects managers and when they remain with the organization and deals with different projects and learn from their experience ultimately their competencies enhance which results in high performance and when these managers with such competencies promoted to top managements then goals of the organization will be achieved easily (Zollo \& Winter, 2002). Organizations required competency for competitive advantage, and employees need career and competency and skill development opportunities. Providing competency development chances to an employee are beneficial for both organization and employees and doing, so organization gains competitive advantage whereas employee gains an opportunity to enhance their competencies (Prince \& Van Eijs, 2005). The organization fails to retain skill when the organization does not provide career opportunities to its employees, and organizations face negative output from their employees (Taylor $\&$ Audia, 1996). The organization fails to retain competency as the project managers face time pressure, stress, and conflict, such environment results in loss of skill (Turner \& Huemann, 2008). Many organizations fail to retain their project managers (Holzle, 2010). Project managers face stress and time and work burden, which positively linked with quitting the job (Aitken \& Crawford, 2007) and that the time when they seek the support of the organization (Allen \& Bryant, 2010) and (Cao \& Hirschi, 2014).

Hypothesis 6: There is a mediating impact of Project Management Competency Retention between Development Perspective of Human Resource Management and Project Success.

\section{Lesson Learned System of KM and Project Success with mediation of PMCR}

Knowledge sharing is one of the factors which help the organization in gaining a competitive advantage (Argote \& Beckman, 1990). Goals and objective of the organization can be achieved in a matchless way when the learning in the organization is on regular basis, (Cyert \& March, 1963) knowledge management is considered as one of the most important factor for the success of a project and performance of organization. Knowledge is an important source which is transferred to organization from the ability of its employees and it is an important source of get competitive advantage (Drucker, 1993). Methods of knowledge management should be followed at the start of the project and at the end of the project all the lesson learned from that project should be collected (Owen \& Burstein, 2005).Value of the organization increases when knowledge is shared and distributed among the employees (Choi, Kim, \& C.M, 2006). Knowledge will be useless when it is not utilized effectively and efficiently (Yusof \& Bakar, 2012). Adoption of knowledge management strategies add value to the organization outputs and this strategy has been extensively adopted by many organizations and it has enhanced the performance of adopted organizations reported by numerous scholars (Tseng, 2014). Learning is crucial and beneficial for the newness of the project in the project based organization as learning improve skill of the employees and enable organization to present their project in a better form (Sammarra \& Biggiero, 2008) their performance enhance and learning enable them to move with the market (Brady \& Davies, 2004) lesson learned system are seen very useful in project based organization and by adopting lesson learned system the performance will not be affected even when employee leave the organization. Competency needed by project managers vary and depend on the nature of the project (Muller \& Turner, 2007) therefore it is an imperative work for the project manager to tackle with different situation effectively and efficiently. The main task of project managers is to use their competency to collaborate with members and perform task according to the project management schedule and within a specific time. To perform the task a project manager should have a competency to fulfill the work efficiently and effectively (Crawford L. , 2000). Project managers are required to combine their entire competence to collaborate and communicate with team members to perform the given task and to get desire results. Organizations deals with project and number of projects are being failed therefore (Bredillet \& Tywoniak, 2015); (Crawford L. , 2005) organizations need competency for quick results which results in increase in the demand of project managers. Project manager should possess a high-level competency to achieve 
success and avoid failure (Napier \& Keil, 2009). Project management competency is to figure out business operation and know-how of skills and understanding of business surroundings (Suikki \& Tromstedt, 2006). For better performance it is crucial to find out competency of every member and tie them to single aim to achieve high performance (Ruuska \& Teigland, 2009). Competency plays a vital role for the success of a project (Jha \& Iyer, 2007).

Hypothesis 7: There is a mediating impact of Project Management Competency Retention between Development Perspective of Human Resource Management and Project Success.

\section{Methods}

Sample, Data collection methods, instrument, sample description, and statistical techniques have discussed in this section. For the collection of data 380 questionnaires were distributed in telecommunication sector (PTCL, Ufone, Warid, Zong, and Mobilink), GEPCO and Sui Northern Gas Pipeline limited of Gujranwala District of Punjab, Pakistan out of which 321 questionnaires were returned, and the study gain an actual response rate of $84.4 \%$. This high response rate is owing to the adoption of a personal administered questionnaire technique. Some questionnaires were excluded because of missing values by using a list-wise deletion method, which includes statistical analysis, and after that 310 complete questionnaires were selected for further proceeding. In the current study, non-probability sampling is used because there is less concern with generalization. It is a general concern to feel the situations and circumstances.

The type of scale used for the questionnaire as an instrument is the "Five Point Likert Scale" with commentators such as 1st Strongly disagree, 2nd Disagree, 3rd Neutral, 4th Agree, and 5th is Strongly disagreed. Respondents respond to the point at which they satisfied with items. The questionnaire items are initially assembled in English. The relationship of Development Perspective of Human Resource Management, Lesson Learned System of Knowledge Management and Project Success with the mediation of Project Management Competency Retention is examined by using the statistical techniques such as "Pearson's Correlation," "Descriptive Statistics," "Factor Analysis" and Structural Equation Modeling (SEM).

\section{Results}

In the present study, SPSS is used to impute the data. Table 7 shows the correlation values of the development perspective of human resource management, lesson learned system of knowledge management, project management competency retention, and project success.

Table 1: Correlation of variables

\begin{tabular}{llcccc}
\hline & & PMCR & PS & DPHRM & LLSKM \\
\hline PMCR & Pearson Correlation & 1 & & & \\
& Sig. (2-tailed) & & & & \\
PS & Pearson Correlation & $-.140^{*}$ & 1 & & \\
\multirow{2}{*}{ DPHRM } & Sig. (2-tailed) & .014 & & & \\
& Pearson Correlation & $-.114^{*}$ & -.007 & \multirow{2}{*}{1} & \\
& Sig. (2-tailed) & .046 & .897 & & \\
LLSKM & Pearson Correlation & -.110 & .062 & $.584^{* *}$ & 1 \\
& Sig. (2-tailed) & .054 & .279 & .000 & \\
\hline
\end{tabular}

*. Correlation is significant at the 0.05 level (2-tailed).

**. Correlation is significant at the 0.01 level (2-tailed).
In case of project management competency retention and project success, the value Sig. (2-tailed) is less than .05 , which shows a statistically significant correlation between project management competency retention and project success. Hence, we can conclude that the project management competency retention has a significant impact on project success.

In the case of the development perspective of human resource management and project success, the value Sig. (2-tailed) is greater than .05 , which means that there is no statistically significant correlation between the development perspective of human resource management and project success. Hence, we can conclude that the development perspective of human resource management has no significant impact on project success.

In the case of lesson learned system of knowledge management and project success, the value Sig. (2-tailed) is greater than .05, which means there is no statistically significant correlation between lesson learned system of knowledge management and project success. Hence, we can conclude that lesson learned system of knowledge management has no significant impact on project success.

To check the consistency of responses or feedback from the respondents, "Reliability Analysis" is performed. To investigate the reliability of the survey, "Cronbach's Alpha" is measured, as shown in table 8 . The range acceptable for Cronbach's alpha is .70 or higher (Bryman \& Bell, 2003).

Table 2: Reliability statistic

\begin{tabular}{lc}
\hline \multicolumn{1}{c}{ Description } & Cronbach's Alpha \\
\hline $\begin{array}{l}\text { In this study value of Cronbach Alpha of all the } \\
\text { variables are within acceptable range. }\end{array}$ & .742
\end{tabular}

\section{Confirmatory Factor Analysis (CFA)}

Confirmatory factor analysis test is required to confirm the adequacy of the conceptual model. Confirmatory analysis test is applied to all the variables separately to verify that the all the values of DF, GFI, RMSEA, CFI, and AGFI are within acceptable ranges. In this study, AMOS 21 is used to run the confirmatory analysis test.

\section{Development Perspective of Human Resource Management}

The questionnaire contains ten items on the development perspective of human resource management to investigate the extent to which the employees of the targeted sectors are satisfied with the development perspective of human resource management in retaining the competency. After applying the confirmatory factor analysis test, only those items were retained, which has factor loadings $>.30$.

Table 3: Confirmatory factor analysis of Development perspective of HRM

\begin{tabular}{|c|c|c|c|}
\hline Statistics & Fit Indices & Acceptable Threshold value & Values \\
\hline \multirow[t]{4}{*}{ Absolute Fit } & CMIN/DF & $1-5$ & 2 \\
\hline & GFI & $>.90$ & .993 \\
\hline & RMR & $<.05$ & .017 \\
\hline & RMSEA & Less or equal to .08 & .057 \\
\hline Incremental Fit & CFI & Greater or equal to .95 & .996 \\
\hline
\end{tabular}

DF = Degree of Freedom; GFI= Goodness of fit index; $R M R=$ Root Mean Square Residual; RMSEA= Root Mean Square Error of Approximation; $C F I=$ Comparative Fit Index and AGFI=Adjusted Goodness of Fit Index. 


\section{Lesson Learned System of Knowledge Management}

The questionnaire contains seven items on lesson learned system of knowledge management to investigate that whether the targeted sectors have an effective lesson learned system or not and its impact on competency retention. After applying the confirmatory factor analysis test, only those items were retained, which has factor loadings $>.30$.

Table 4: Confirmatory factor analysis of learned system of knowledge management

\begin{tabular}{llll}
\hline Statistics & $\begin{array}{l}\text { Fit } \\
\text { Indices }\end{array}$ & Acceptable Threshold value & Values \\
\hline Absolute Fit & GFI & $>.90$ & 1.00 \\
& RMR & $<.05$ & .000 \\
& RMSEA & Less or equal to .08 & .453 \\
Incremental Fit & CFI & Greater or equal to .95 & 1.00
\end{tabular}

$\overline{D F}=$ Degree of Freedom; GFI= Goodness of fit index; RMR= Root Mean Square Residual; RMSEA= Root Mean Square Error of Approximation; CFI= Comparative Fit Index and AGFI= Adjusted Goodness of Fit Index.

\section{Project Management Competency Retention}

The questionnaire contains five items on project management competency retention to investigate whether the targeted sectors can retain their competency in project management. After applying the confirmatory factor analysis test, only those items were retained, which has factor loadings $>.30$.

Table 5: Confirmatory factors analysis of Project Management Competency Retention

\begin{tabular}{|c|c|c|c|}
\hline Statistics & Fit Indices & Acceptable Threshold value & Values \\
\hline \multirow{4}{*}{ Absolute Fit } & CMIN/DF & $1-5$ & 13.621 \\
\hline & GFI & $>.90$ & .957 \\
\hline & RMR & $<.05$ & .062 \\
\hline & RMSEA & Less or equal to .08 & .202 \\
\hline Incremental Fit & CFI & Greater or equal to .95 & .958 \\
\hline
\end{tabular}

$D F=$ Degree of Freedom; GFI $=$ Goodness of fit index; $R M R=$ Root Mean Square Residual; RMSEA = Root Mean Square Error of Approximation; CFI= Comparative Fit Index and AGFI= Adjusted Goodness of Fit Index.

\section{Project Success}

The questionnaire contains nine items on project success to investigate whether the employees of the targeted sectors are well about the project management to achieve project success. After applying the confirmatory factor analysis test, only those items were retained, which has factor loadings $>.30$.

Table 6: Confirmatory factors analysis of Project Success

\begin{tabular}{llll}
\hline Statistics & Fit Indices & Acceptable Threshold value & Values \\
\hline \multirow{4}{*}{ Absolute Fit } & CMIN/DF & $1-5$ & 1.628 \\
& GFI & $>.90$ & .984 \\
Incremental Fit & RMR & $<.05$ & .030 \\
& RMSEA & Less or equal to .08 & .045 \\
& CFI & Greater or equal to .95 & .991 \\
\hline
\end{tabular}

$D F=$ Degree of Freedom; GFI $=$ Goodness of fit index; $R M R=$ Root Mean Square Residual; RMSEA= Root Mean Square Error of Approximation; CFI= Comparative Fit Index and AGFI= Adjusted Goodness of Fit Index.

Structural Equation Modeling (SEM)

This study path analysis has been shown by using structural equation modeling (SEM) through AMOS 21. Figure 5 shows the model which represents the relationship among the development perspective of human resource, lesson learned system of knowledge management, project management competency retention and project success which was further measured through standard estimate to find whether there is a statistically significant relationship exist between them or not and the results has been shown in table 13.

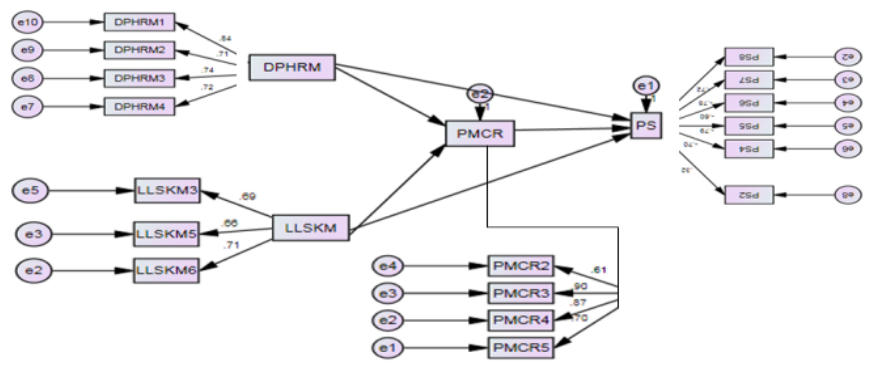

Figure 1: Structural Analysis of Path Model

Table 7: Standardized Estimate of Path Analysis

\begin{tabular}{llllccc}
\hline \multicolumn{1}{c}{} & & & Estimate & S.E. & C.R. & P \\
\hline PMCR & $<--$ & DPHRM & -.079 & .073 & -1.081 & .280 \\
PMCR & $<--$ & LLSKM & -.078 & .082 & -.949 & .343 \\
PS & $<---$ & PMCR & -.097 & .040 & -2.441 & .015 \\
PS & $<--$ & DPHRM & -.056 & .051 & -1.099 & .272 \\
PS & $<---$ & LLSKM & .075 & .057 & 1.313 & .189 \\
\hline
\end{tabular}

DPHRM=development perspective of human resource management;
LLSKM=lesson learned system of knowledge management; PMCR=project management competency retention; $P S=$ project success.

\section{DISCUSSION}

This section debates on the results offered in the preceding chapter. Initially, a recap of the outcomes and arguments are presented. Hypothetical and practical implications of the results are discussed. The chapter ends at outline further research directions and conclusion.

Hypothesis 1: "There is a significant Positive relationship between Development Perspective of Human Resource Management and Project Management Competency Retention". An insignificant positive relationship between development perspective of human resource management and project management competency retention has been proved in this study. As this research has been conducted in Pakistan, most of the organization in Pakistan are failed to retain competency due to its poor HR system. A study conducted in Ghana Vodafone company founded that competency can be retain by organization when it satisfied their employee's needs, provide career path and better working environment to its employees (Kwenin, Muathe, \& Nzulwa, 2013). On the other hand it does not solely depend on HR system to retain competency, even if the organization provides better training to its employees, that enhance their skills and abilities then there may be a chance that it creates more and better opportunity for them in the market (Smith \& Oczkowski, 2011). Therefore, the results did not support the researcher's hypothesis that there is a significant positive relationship between development perspective of human resource management and project management competency retention.

Hypothesis 2: "There is a significant Positive relationship between Development Perspective of Human Resource Management and Project Success".

An insignificant positive relationship between the development perspective of human resource management and project success has been proved in this study. This research has been conducted in 
Pakistan. Most organizations in Pakistan have failed to retain their project managers for an extended period due to its weak HR system. Project managers usually do not have long term future perspectives on a certain position in an organization due to the time-bound nature of the project for which their services are hired by an organization that is not a permanent entity (El-Sabaa, 2001). Therefore, the results did not support the researcher's hypothesis that there is a significant positive relationship between the development perspective of human resource management and project success.

Hypothesis 3: "There is a significant Positive relationship between Lesson Learned System of Knowledge Management and Project Management Competency Retention".

An insignificant positive relationship between a lesson learned system of knowledge management and project management competency retention was proven. Most organizations relocate their project managers without retaining lessons learned in the previous project to be used in future projects. Still, the competency enhanced during the project remain in the organization (Disterer, 2002). As this research has been conducted in Pakistan, most of the organizations in Pakistan are failed to retain competency because when the employees get a better opportunity, they leave the organization and skill attach with them also go with them. Therefore, the results did not support the researcher's hypothesis that there is a significant positive relationship between lesson learned system of knowledge management and project management competency retention.

Hypothesis 4: “There is a significant Positive relationship between Lesson Learned System of Knowledge Management and Project Success".

An insignificant positive relationship between a lesson learned system of knowledge management and project success had been proved in this study. Employees of the organization might not share their knowledge with others in the organization. It may be possible that resentment and competition between the departments stop employees from sharing their knowledge (Ashforth \& Maell, 1989). Knowledge sharing is the process by which one department of the company is distressed by others (Levitt \& March, 1988; Argoti \& Beckman, 1990). e.g., one department gains experience from other departments and start to work more efficiently from that department from which it gains experience. Therefore, the results did not support the researcher's hypothesis that there is a significant positive relationship between lesson learned system of knowledge management and project success.

Hypothesis 5: "There is a significant Positive relationship between Project Management Competency Retention and Project Success".

Results, as shown in table 13 , indicate that there is a significant positive relationship between project management competency retention and project success $(\mathrm{P}<.05)$. The results supported the researcher's hypothesis that there is a meaningful positive relationship between project management competency retention and project success.

Hypothesis 6: "There is a mediating impact of Project Management Competency Retention between Development
Perspective of Human Resource Management and Project Success".

In this study, the researcher hypothesized mediating impact of project management competency retention between the development perspective of human resource management and project success. The results reveal an insignificant relationship of development perspective of human resource management with project management competency retention and project success. Therefore, no mediation was proved. So, the researcher's hypothesis was not supported.

Hypothesis 7: “There is a mediating impact of Project Management Competency Retention between Lesson Learned System of Knowledge Management and Project Success".

In this study, the researcher hypothesized the mediating impact of project management competency retention between a lesson learned system of knowledge management and project success. Still, the results reveal an insignificant relationship of the lesson learned system of knowledge management with project management competency retention and project success. Therefore, no mediation was proved. So, the researcher's hypothesis was not supported.

\section{Practical Implication}

Recent research has considerable practical implications. Organizations should, based on evidence, try to adopt strategies that help organizations achieve success in the projects. A significant positive relationship has been found in project management competency retention and project success. Organizations should eliminate those factors which fail the organization to retain competency. The organization should understand that every employee has some desire which should be satisfied for retaining the employees in the organization.

Moreover, to increase the productivity of the employees. One can do so (Hayes, Rose-Quirie, \& Allinson, 2000) by observing the duties and responsibilities of the managers at the workplace by questioning them about their competency need to perform their work effectively and by adopting techniques like interviewing and questionnaire. By applying these techniques organization would be able to retain its competency and would be able to achieve success in the projects.

\section{Limitation and future research directions}

This study has some limitations which provide directions for future research. First, an insignificant relationship has been found between the development perspective of human resource management and project management competency retention. It would be beneficial to investigate the cultural impact on project management competency retention (Holtom, 2008). This study has investigated the effect of only two independent variables: the development perspective of human resource management. Lesson learned system of knowledge management. There are many other variables like organizational environment, market conditions, perceived organizational support, project management competency retention, and project success. Secondly, the sample has been drawn from the Gujranwala district of Punjab, Pakistan. Thus, the results can be tested in other regions of Punjab and other provinces of Pakistan. 


\section{Conclusion}

The contribution of this study is imperative in existing knowledge of development perspective of human resource management, lesson learned system of knowledge management, project management competency retention, and project success. The relationship of development perspective of human resource management, lesson learned system of knowledge management, and project success with the mediation of project management competency retention is examined by using the statistical techniques such as "Pearson's Correlation," "Descriptive Statistics" and "Factor Analysis." This study is based on the sample of employees from the telecom sector, GEPCO, and SNGPL Pakistan. The findings confirmed that the development perspective of human resource management and lesson learned system of knowledge management has an insignificant positive relationship with project management competency retention and project success. There is no mediation of project management competency retention that has been proved between the development perspective of human resource management, lesson learned system of knowledge management, and project success. A significant positive relationship has been shown between project management competency retention and project success. The results of this study suggested that the organizations must retain competency to achieve project success. This study is supposed to help management retain skills to achieve success in the projects.

\section{References}

Abdullateef, A., \& Mokhtar, S. (2010). The impact of CRM dimensions on call center performance. International Journal of Computer Science and Network Security, 10(12), 184-195.

Aitken, A., \& Crawford, L. (2007). Coping with stress: Dispositional coping strategies of project managers. . International Journal of Project Management, 25(7), 666-673.

Alavi, M., \& Leidner, D. (1999). Knowledge management systems: issues, challenges, and benefits. . Communications of the AIS, $1(2 e s), 1$.

Alavi, M., \& Leidner, D. (2001). Review: Knowledge management and knowledge management systems: Conceptual foundations and research issues. MIS quarterly, 107-136.

Allen, D., \& Bryant, P. (2010). Retaining talent: Replacing misconceptions with evidence-based strategies. The Academy of Management Perspectives, 24(2), 48-64.

Allen, D., \& Shore, L. (2003). The role of perceived organizational support and supportive human resource practices in the turnover process. Journal of Management, 29(1), 99-118.

Argoti, L., \& Beckman, S. (1990). The persistence and transfer of learning in industrial settings. . Management Science, 36(2), 140-154.

Ashforth, B., \& Maell, F. (1989). Social identity theory and the organization. Academy of Management Review, 14(1), 20-39.

Bates, R., \& Chen, H. (2004). Human resource development value orientations: A construct validation study. Human Resource Development International, 7(3), 351-370.

Baum, J., \& Ingram, P. (1998). Survival-enhancing learning in the Manhattan hotel industry, 1898-1980. Management Science, 44(7), 996-1016.
Becerra-Fernandez, R. (2001). Organizational knowledge management: A contingency perspective. . Journal of Management Information Systems, 18(1), 23-55.

Bell, B., \& Kozlowski, S. (2008). Active learning: effects of core training design elements on self-regulatory processes, learning, and adaptability. Journal of Applied Psychology, 93(2), , 296.

Bernard, Oyagi, N., Appolonius, \& Kembu, S. (2014). To assess the relationship between motivation and retention of academic staff in selected public higher institutions of learning in Dar essalaam. International Journal of Advancement in Engineering Technology. Management \& Applied Science, 1(4), , 54-61.

Brady, T., \& Davies, A. (2004). Building project capabilities: From exploratory to exploitative learning. Organization Studies, 25(9), , 1601-1621.

Bredillet, C., \& Tywoniak, S. (2015). What is a good project manager? An Aristotelian perspective. International Journal of Project Management, 33(2), 254-266.

Bredin, K., \& Soderlund, J. (2013). Project managers and career models: An exploratory comparative study. International journal of project management, 31(6), 889-902.

Bryman, A., \& Bell, E. (2003). Breaking down the quantitative/qualitative divide. Business Research Methods, 465-478.

Burnt, M., \& Dutsch, J. (2013). Competency-based training and assessment center: Strategies, technology, process, and issues. Advances in Developing Human Resources, 8(2), 141-143.

Caldas, C., \& Gibson, J. (2009). Identification of effective management practices and technologies for lessons learned programs in the construction industry. Journal of Construction Engineering and Management, 135(6), 531-539.

Cao, L., \& Hirschi, A. (2014). Perceived organizational support and intention to stay in host countries among self-initiated expatriates: the role of career satisfaction and networks. The International Journal of Human Resource Management, 25(14), 2013-2032.

Cho, T. (2011). Knowledge management capabilities and organizational performance: An investigation into the effects of knowledge infrastructure and processes on organizational performance (Doctoral dissertation, University of Illinois at Urbana-Champaign).

Choi, D., Kim, \& C.M. (2006). Customer loyalty and disloyalty in internet retail stores: its antecedents and its effect on customer price sensitivity. International Journal of Management, 23(4), 925.

Collins, C., \& Smith, K. (2006). Knowledge exchange and combination: The role of human resource practices in the performance of high-technology firms. Academy of Management Journal, 49(3), 544-560.

Crawford, L. (2007). Developing the project management competence of individuals. In J. R. Turner . Gower Handbook of Project Management , 678-694.

Crawford, L. (2000). Profiling the competent project manager. In Proceedings of PMI Research Conference (pp. 3-15). Newton Square, PA: Project Management Institute. 
Crawford, L. (2005). Senior management perceptions of project management competence. . International Journal of Project Management, 23(1), 7-16.

Cyert, R., \& March, J. (1963). A behavioral theory of the firm. Englewood Cliffs, NJ, 2.

Darr, E., \& Argote, L. (1995). The acquisition, transfer, and depreciation of knowledge in service organizations: Productivity in franchises. Management Science, 41(11), 17501762.

Defillippi, R., \& Arthur, M. (1998). Paradox in project-based enterprise: The case of film making. . California Management Review, 40(2), 125-139.

Desouza, K., \& Paquette, S. (2011). Knowledge management: An Introduction. New York: NY: Neal-Schuman Publishers, Inc.

Devenport, T., \& Prusak, L. (1998). Working knowledge: . How organizations manage what they know. Harvard Business Press

Disterer, G. (2002). Management of project knowledge and experiences. Journal of Knowledge Management, 6(5), 512-520.

Drucker, P. (1993). The rise of the knowledge society. Wilson Quarterly, 17(2), 52-71.

Dul, J., Canan, \& Ceylan. (2011). Knowledge workers' creativity and the role of the physical work environment. Human Resource Management, 50(6), 715-734.

Egbu, C. (2000). Knowledge management in construction SMEs: coping with the issues of structure, culture, commitment and motivation. In ARCOM Sixteenth Annual Conference, 83-92.

Elattar, S. (2009). Towards developing an improved methodology for evaluating performance and achieving success in construction projects. Scientific Research and Essays, 4(6), 549554.

El-Sabaa. (2001). The skills and career path of an effective project manager. International Journal of Project Management, 19(1), 1-7.

Fenwick, T., \& Bierema, L. (2008). Corporate social responsibility: issues for human resource development professionals. International Journal of Training and Development, 12(1), 24-35.

Gerush, M. (2009). Define, Hire, And Develop Your NextGeneration Project Managers. . Forrester Research Inc.

Gholami, M., \& Asli, M. (2013). Investigating the influence of knowledge management practices on organizational performance: an empirical study. Acta Polytechnica Hungarica, 10(2), 205-216.

Goh, S. (2002). Managing effective knowledge transfer: an integrative framework and some practice implications. Journal of Knowledge Management, 6(1), 23-30.

Grant, R. (1996). Prospering in dynamically-competitive environments: Organizational capability as knowledge integration. Organization Science, 7(4), 375-387.

Gubbins, C., \& Garavan, T. (2006). Enhancing the role of the HRD function: The case of a health services organisation. Irish Journal of Management, 27(1), 171.

Guthrie, J. (2001). High-involvement work practices, turnover, and productivity: Evidence from New Zealand. Academy of Management Journal, 44(1), 180-190.
Hayes, J., Rose-Quirie, A., \& Allinson, C. (2000). Senior managers' perceptions of the competencies they require for effective performance: implications for training and development. Personnel Review, 29(1), 92-105.

Hoegl, M., \& Schulze, A. (2005). How to Support Knowledge Creation in New Product Development:An Investigation of Knowledge Management Methods. European Management Journal, 23(3), 263-273.

Holtom. (2008). Chapter 5: turnover and retention research: a glance at the past, a closer review of the present, and a venture into the future. Academy Management Annual, 2(1), 231-274.

Holzle, K. (2010). Designing and implementing a career path for project managers. International Journal of Project Management, 28(8), 779-786.

Huselid, M. (1995). The impact of human resource management practices on turnover, productivity, and corporate financial performance. Academy of management journal, 38(3), 635-672.

Hutchings, K., Zhu, C., \& Cooper, B. (2009). Perceptions of the effectiveness of training and development of 'greycollar'workers in the People's Republic of China. Human Resource Development International, 12(3), 279-296.

Indradevi, R. (2010). Training for most capable workforce. Advances in Management.

Jha, K., \& Iyer, K. (2007). Commitment, coordination, competence and the iron triangle. International Journal of Project Management, 25(5), 527-540.

Kerzner, H. (1987). "In search of excellence in project management". Journal of Systems Management, 38(2), 30-40.

Kotnour, T. (2000). Organizational learning practices in the project management environment. International Journal of Quality \& Reliability Management, 17(4/5), 393-406.

Kuchinke, K. (2010). Human development as a central goal for human resource development. Human Resource Development International, 13(5), 575-585.

Kwenin, D., Muathe, S., \& Nzulwa, R. (2013). The influence of employee rewards, human resource policies and job satisfaction on the retention of employees in Vodafone Ghana Limited. European Journal of Business and Management, 5(12), 13-20.

Laser, S. (1980). Dealing with the problem of employee turnover. Human Resource Management, 19(4), 17-21.

Levitt, B., \& March, J. (1988). Organizational learning. Annual Review of Sociology, 14(1), 319-338.

Liu, \& A, W. (1998). "Evaluation of Project Outcomes". Construction Management and Economics, 16, 209-219.

Liu, A. (2005). The mythical CSFs in Project Procurement, 2004, Paper presented during the 7th Surveyors' Congress on $21-22$ June 2005 in Kuala Lumpur.

Madiha et al. (2009).

Masterson, S., \& Stamper, C. (2003). Perceived organizational membership: An aggregate framework representing the employee-organization relationship. Journal of Organizational Behavior, 24(5), 473-490.

Maznevski, M. (1994). Understanding our differences: Performance in decision-making groups with diverse members. Human Relations, 47(5), 531-552. 
Meshkendahl, S. (2010). The influence of business strategy on project portfolio management and its success - a conceptual framework. International Journal of Project Management, 28(8), 807-817.

Metaxiotis, K., \& Ergazakis, K. (2005). Exploring the world of knowledge management: agreements and disagreements in the academic/practitioner community. Journal of Knowledge Management, 9(2), 6-18.

Mir, F.A, \& Pinnington, A. (2014). ). Exploring the value of project management: linking project management performance and project success. International Journal of Project Management, 32(2), 202-217.

Muller, R., \& Turner, R. (2007). The influence of project managers on project success criteria and project success by type of project. European Management Journal, 25(4), 298-309.

Napier, N., \& Keil, M. (2009). IT project managers' construction of successful project management practice: a repertory grid investigation. Information Systems Journal, 19(3), 255-282.

Newell, S., \& Edelman, L. (2008). Developing a dynamic project learning and cross-project learning capability: synthesizing two perspectives. Information Systems Journal, 18(6), 567-591.

Ng, T., \& Butts, M. (2009). Effectiveness of organizational efforts to lower turnover intentions: The moderating role of employee locus of control. Human Resource Management, 48(2), 289310.

Noe, R., Tews, M., \& Dachner, A. (2010). Learner engagement: A new perspective for enhancing our understanding of learner motivation and workplace learning. Academy of Management Annals, 4(1), 279-315.

Nonaka, I. (1994). A dynamic theory of organizational knowledge creation. Organization Science, 5(1), 14-37.

Nonaka, I., \& Takeuchi, H. (1995). The knowledge-creating company: How Japanese companies create the dynamics of innovation. Oxford university press.

Nonaka, I., \& Toyama, R. (2000). SECI, Ba and leadership: A unified model of dynamic knowledge creation. Long Range Planning, 33(1), 5-34.

Owen, J., \& Burstein, F. (2005). Where Knowledge Management Resides within Project Management,[w:] M. Jennex (red.). Case Studies in Knowledge Management, Idea Group Inc.

Packendorff, J. (2002). The temporary society and its enemies: projects from an individual perspective. Beyond Project Management: New Perspective on the Temporary-Permanent Delimma. Copenhagen Business School Press, Copenhagen, 39-58.

Paranagamage, P., \& Carrillo, P. (2012). Lessons learned practices in the UK construction sector: current practice and proposed improvements. Engineering Project Organization Journal, 2(4), 216-230.

Patton, M. (2001). Evaluation, knowledge management, best practices, and high quality lessons learned. American Journal of Evaluation, 22(3), 329-336.

Phillips, J. (1998). Effects of realistic job previews on multiple organizational outcomes:. A meta-analysis. Academy of Management Journal, 41(6), 673-690.
Powell, W., \& Koput, K. (1996). Interorganizational collaboration and the locus of innovation: Networks of learning in biotechnology. Administrative Science Quarterly, 116-145.

Prince, K., \& Van Eijs, P. (2005). General competencies of problem-based learning (PBL) and non-PBL graduates. Medical Education, 39(4), 394-401.

Riege. (2007). Actions to overcome knowledge transfer barriers in MNCs. Journal of Knowledge Management 11(1), 48-67.

Ruuska, I., \& Teigland, R. (2009). Ensuring project success through collective competence and creative conflict in publicprivate partnerships-A case study of Bygga Villa, a Swedish triple helix e-government initiative. International Journal of Project Management, 27(4), 323-334.

Sammarra, A., \& Biggiero, L. (2008). Heterogeneity and specificity of Inter-Firm knowledge flows in innovation networks. Journal of Management Studies, 45(4), 800-829.

Schindler, M., \& Eppler, M. (2003). Harvesting project knowledge: a review of project learning methods and success factors. International Journal of Project Management, 21(3), 219-228.

Senaratne, S., \& Malewana, C. (2011). Linking individual, team and organizational learning in construction project team settings. Architectural Engineering and Design Management, 7(1), 50-63.

Shenhar, A., Levy, O, \& Davir, D. (1997). Mapping the dimensions of project success. Project Management Journal, 28(2), 5-13.

Smith, A., \& Oczkowski, E. (2011). To have and to hold: modelling the drivers of employee turnover and skill retention in Australian organisations. The International Journal of Human Resource Management, 22(02), 395-416.

Spender, J., \& Grant, R. (1996). Knowledge and the firm: overview. Strategic Management Journal, 17(S2), 5-9.

Suikki, R., \& Tromstedt, R. (2006). Project management competence development framework in turbulent business environment. Technovation, 26(5), 723-738.

Suraj, O., \& Ajiferuke, I. (2013). Knowledge management practices in the Nigerian telecommunications industry. Knowledge and Process Management, 20(1), 30-39.

Swart, J. (2012). HRM, innovation and looking across boundaries, Seminar Series on Organizational Innovation, People Management and Sustained Performance, Aston University, Birmingham, October.

Taylor, M., \& Audia, G. (1996). The effect of lengthening job tenure on managers' organizational commitment and turnover. Organization Science, 7(6), 632-648.

Teece, D., \& Pisano, G. (1997). Dynamic capabilities and strategic management. Strategic Management Journal, 509-533.

Tseng, S. (2014). The impact of knowledge management capabilities and supplier relationship management on corporate performance. International Journal of Production Economics, 154, 39-47.

Turner, J., \& Keegan, A. (2008). Human resource management in the project-oriented organization. Project Management Institute. 
Turner, R., \& Huemann, M. (2008). Human resource management in the project-oriented organization: employee well-being and ethical treatment. International Journal of Project Management, 26(5), 577-585.

Wateridge, J. (1998). How can IS/IT projects be measured for success. International Journal of Project Management, 16(1), 59-63.

Yusof, M., \& Bakar, A. (2012). Knowledge management and growth performance in construction companies: a framework. Procedia-Social and Behavioral Sciences, 62, 128-134.

Zollo, M., \& Winter, S. (2002). Deliberate learning and the evolution of dynamic capabilities. Organization science, 13(3), 339-351.

Zollo, M., \& Winter, S. (2002). Deliberate learning and the evolution of dynamic capabilities. Organization science, 13(3), 339-351. 